\title{
$\alpha$-Trifluoromethyl Chalcones as Potent Anticancer Agents for Androgen Receptor-Independent Prostate Cancer
}

\author{
Yohei Saito ${ }^{1}$, Atsushi Mizokami ${ }^{2}{ }^{*}$ D, Kouji Izumi ${ }^{2}$, Renato Naito $^{2}$, Masuo Goto ${ }^{3}$ (D) and \\ Kyoko Nakagawa-Goto ${ }^{1,3, *(D)}$
}

1 School of Pharmaceutical Sciences, College of Medical, Pharmaceutical and Health Science, Kanazawa University, Kanazawa 920-1192, Japan; saito-y@staff.kanazawa-u.ac.jp

2 Department of Integrative Cancer Therapy and Urology, School of Medical Sciences, Kanazawa University, Kanazawa 920-1192, Japan; kouji1974@staff.kanazawa-u.ac.jp (K.I.); thealfuu@yahoo.co.jp (R.N.)

3 Chemical Biology and Medicinal Chemistry, Eshelman School of Pharmacy, University of North Carolina, Chapel Hill, NC 27599, USA; goto@med.unc.edu

* Correspondence: mizokami@staff.kanazawa-u.ac.jp (A.M.); kngoto@p.kanazawa-u.ac.jp (K.N.-G.); Tel.: +81-76-265-2393 (A.M.); +81-76-264-6305 (K.N.-G.)

\section{check for} updates

Citation: Saito, Y.; Mizokami, A.; Izumi, K.; Naito, R.; Goto, M.; Nakagawa-Goto, $\mathrm{K}$. $\alpha$-Trifluoromethyl Chalcones as Potent Anticancer Agents for Androgen Receptor-Independent Prostate Cancer. Molecules 2021, 26, 2812. https://doi.org/10.3390/ molecules26092812

Academic Editor: Maria Emília de Sousa

Received: 19 April 2021

Accepted: 6 May 2021

Published: 10 May 2021

Publisher's Note: MDPI stays neutral with regard to jurisdictional claims in published maps and institutional affiliations.

Copyright: (c) 2021 by the authors. Licensee MDPI, Basel, Switzerland. This article is an open access article distributed under the terms and conditions of the Creative Commons Attribution (CC BY) license (https:/ / creativecommons.org/licenses/by/ $4.0 /)$.

\begin{abstract}
Trifluoromethyl chalcones were prepared and evaluated for their antiproliferative activities against androgen-independent prostate cancer cell lines as well as five additional types of human tumor cell lines. The most potent chalcone 5 showed superior antitumor activity in vivo with both oral and intraperitoneal administration at $3 \mathrm{mg} / \mathrm{kg}$. Cell-based mechanism of action studies demonstrated that 5 induced cell accumulation at sub-G1 and G2/M phases without interfering with microtubule polymerization. Furthermore, several cancer cell growth-related proteins were identified by using chalcone 5 as a bait for the affinity purification of binding proteins.
\end{abstract}

Keywords: chalcone; trifluoromethyl group; prostate cancer; antitumor activity; target proteins

\section{Introduction}

A small change in a chemical structure sometimes induces a big change in a biological profile. The features of substituents on a bioactive molecule influence the various interactions between it and its target protein and subsequently affect its selectivity and potency, as we have previously reported [1,2]. Fluorine's unique properties, such as small atomic size and high electronegativity, impact $\mathrm{pKa}$, molecular conformation, binding affinity with target molecules, membrane permeability, metabolic pathways, and pharmacokinetic properties of bioactive molecules. Accordingly, fluorine attracts attention in drug discovery and development [3]. In our continuing structure-activity relationship (SAR) study of chalcone derivatives as anti-prostate cancer agents $[4,5]$, we explored whether the insertion of fluorine and/or a fluorinated functional group into synthetic chalcones would improve their activity. Chalcone, a biosynthetic intermediate of various flavonoids, is composed of two aromatic rings connected by $\alpha, \beta$-unsaturated carbonyl unit. Initially, we introduced a trifluoromethyl $\left(\mathrm{CF}_{3}\right)$ group, a known electron withdrawing group, at the $\alpha$-position of the olefin. This group might accelerate Michael addition of a nucleophile in biomolecules, such as the $\mathrm{SH}$ in cysteine [6]. $\mathrm{CF}_{3}$ has been also used as an isostere of a methyl group or amide $\mathrm{C}=\mathrm{O}$ bond with the aim of improving metabolic stability and hydrophobicity in drug development [7]. Secondly, we introduced electron withdrawing groups on the aromatic ring connected to the olefinic double bond of the $\alpha-\mathrm{CF}_{3}$ chalcones. The synthesized $\alpha-\mathrm{CF}_{3}$ analogues were evaluated for anti-prostate cancer activity.

In many cases, prostate cancer progresses slowly and is generally controllable by hormone therapy and/or castration. However, the cancer can reoccur after several years and then is termed castration-resistant prostate cancer (CRPC). Currently, no effective treatment exists for CRPC. Prostate cancer is associated with androgen-receptors (ARs), 
and prostate cancer cells grow in response to androgen. While hormone therapy suppresses androgen secretion and restrains cancer cell growth, continued treatment for several years often leads to diminished effectiveness due to the induction of mutations on the AR, which then can be activated by only a small amount of androgen or independently of constitutive active ligand [8]. In addition, the emergence of prostate cancer that lacks AR expression accelerates its malignancy. In this study, the synthesized $\alpha-\mathrm{CF}_{3}$ chalcones were assayed against DU145 and PC-3 cell lines, which do not express ARs, to evaluate their effectiveness against CRPC. The most potent derivative was further investigated in mode of action studies, including identification of target proteins, and for in vivo antitumor effects. The differences of intracellular targets of previously reported $\alpha$-substituted chalcones [9-11] were also discussed.

\section{Results and Discussion}

\subsection{Chemistry}

The novel $\alpha$-trifluoromethyl chalcones (2-7) and known 1 [12], were synthesized from the related chalcones [13-16] including novel 10 and 11, which were obtained by Claisen-Schmidt condensation of aryl methyl ketones and aromatic aldehydes. In target compounds 1-7, the aromatic aldehyde was either unsubstituted or substituted with one of three electron withdrawing groups $\left(\mathrm{F}, \mathrm{CF}_{3}\right.$, or $\left.\mathrm{NO}_{2}\right)$ or an electron donating group $\left(\mathrm{NMe}_{2}\right)$ for comparative purposes. The $\mathrm{CF}_{3}$ moiety was inserted at the $\alpha$-position of the chalcones by using 1-trifluoromethyl-1,2-benziodoxol-3(1H)-one (Togni reagent) [17] in the presence of $\mathrm{CuI}$ at $80{ }^{\circ} \mathrm{C}$ using a reported method (Scheme 1) [18]. In 6, the chalcone ring-A was changed from benzene to naphthalene and, in derivative 7 , the chalcone ring- $B$ was replaced with benzothiophene, since potent antiproliferative effects were observed with other flavonoids containing $10 \pi$-electron aromatic ring systems $[1,19,20]$. It should be noted that the conformation of the olefin in the resulting $\alpha-\mathrm{CF}_{3}$ chalcones is cis rather than trans as in the natural chalcone, which has been confirmed with X-ray crystal structure analysis by Bi et al. [18] and might also affect the biological activities. Spectroscopic data of all newly synthesized compounds are in Supplementary Materials (Figures S1-S40).

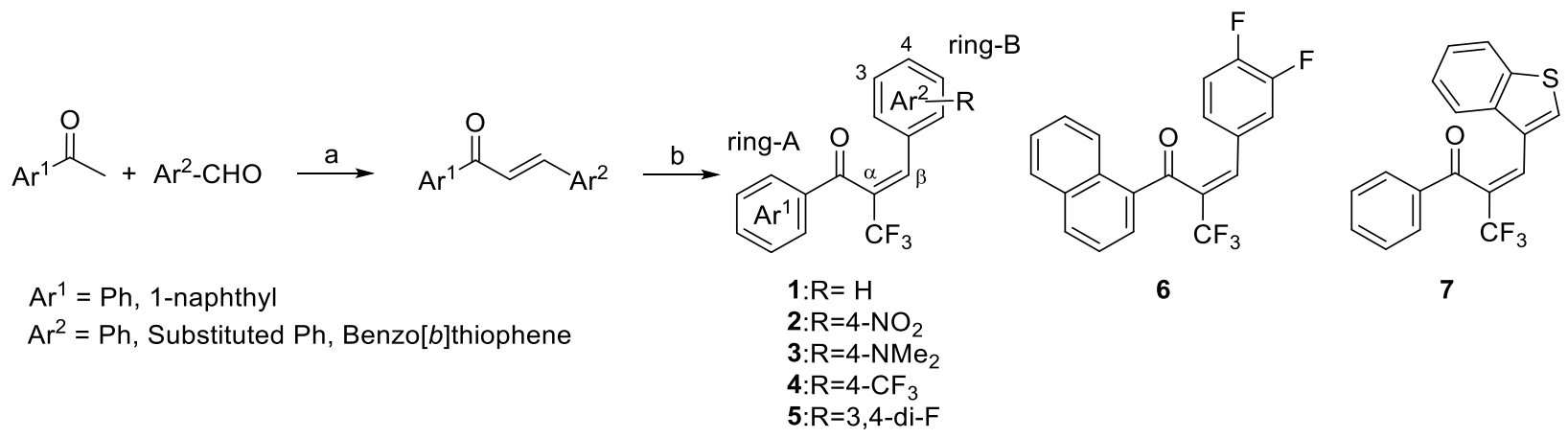

Scheme 1. Synthesis of $\alpha-\mathrm{CF}_{3}$ chalcones ${ }^{a} .{ }^{a}$ Reagents and conditions: (a) $40 \% \mathrm{KOH}, \mathrm{EtOH}$, room temp. (b) 1-Trifluoromethyl1,2-benziodoxol-3(1H)-one, CuI, DMF, $80{ }^{\circ} \mathrm{C}$.

\subsection{Biological Evaluation}

Antiproliferative Activity of Compounds against AR-Independent Cells

The antiproliferative activities of the synthesized $\alpha-\mathrm{CF}_{3}$ chalcones against AR-independent cell lines, DU145 and PC-3 were evaluated (Table 1). 5'-Chloro-2,2'-dihydroxychalcone (Cl-DHC), which was found as a potent antiproliferative chalcone by our group [5], was used as a control. All $\alpha-\mathrm{CF}_{3}$ chalcones showed potent activity; especially $4-\mathrm{NO}_{2}$ chalcone 2 and 3,4-difluorochalcone 5 strongly inhibited the growth of both tumor cell lines with $\mathrm{IC}_{50}$ values of less than $0.2 \mu \mathrm{M}$. These results indicated the insertion of $\mathrm{CF}_{3}$ at the $\alpha$-position was beneficial to the antiproliferative activity, since most of the potent compounds among our previously synthesized chalcones without an $\alpha-\mathrm{CF}_{3}[4,5]$ exhibited $\mathrm{IC}_{50}$ values of over $5 \mu \mathrm{M}$. 
Regarding the chalcone ring-A, although the $\alpha-\mathrm{CF}_{3}$ chalcone 6 with a naphthyl ring-A was active, it was threefold less potent than the analogous chalcone 5 with a phenyl ring-A. Among this limited compound set, electron withdrawing groups on ring-B resulted in slightly improved antiproliferative activity, as the non-substituted chalcone 1 and $4-\mathrm{NMe}_{2}$ chalcone 3 were less potent than $4-\mathrm{NO}_{2} 2,4-\mathrm{CF}_{3}$ 4, and 3,4-difluoro 5.

Table 1. Antiproliferative activity against androgen-independent prostate cancer cell lines, DU145 and PC-3.

\begin{tabular}{cccccc}
\hline & \multicolumn{2}{c}{ Cell Lines/IC 50 $(\mu \mathrm{M})^{\mathbf{a}}$} & & \multicolumn{2}{c}{ Cell Lines/IC $\mathbf{5 0}^{\mathbf{a}}(\boldsymbol{\mu M})^{\mathbf{a}}$} \\
Compounds & DU145 & PC-3 & Compounds & DU145 & PC-3 \\
\hline $\mathbf{1}$ & $0.69 \pm 0.30$ & $0.44 \pm 0.06$ & $\mathbf{5}$ & $0.19 \pm 0.04$ & $0.15 \pm 0.03$ \\
$\mathbf{2}$ & $0.19 \pm 0.01$ & $0.15 \pm 0.02$ & $\mathbf{6}$ & $0.54 \pm 0.05$ & $0.44 \pm 0.12$ \\
$\mathbf{3}$ & $0.94 \pm 0.27$ & $0.44 \pm 0.03$ & $\mathbf{7}$ & $1.44 \pm 0.18$ & $1.07 \pm 0.18$ \\
$\mathbf{4}$ & $0.45 \pm 0.05$ & $0.46 \pm 0.01$ & Cl-DHC $^{\mathrm{b}}$ & $4.50 \pm 0.89$ & $1.52 \pm 0.25$ \\
\hline
\end{tabular}

a The concentration of compound that caused $50 \%$ reduction of cell growth relative to untreated cells determined by cell counting. The values are average $\pm \mathrm{SD}$ of three independent experiment. ${ }^{\mathrm{b}} 5^{\prime}$-Chloro-2,2'-dihydroxychalcone, which was previously synthesized by our group [5].

All synthesized chalcones were also assayed against five additional human tumor cell lines, non-small cell lung (A549), triple-negative breast (MDA-MB-231), estrogen-responsible breast (MCF-7), cervical cancer cell line HeLa derivative (KB), and P-glycoprotein (P-gp) overexpressing multidrug resistant $\mathrm{KB}$ subline (KB-VIN). Again, the chalcones containing electron withdrawing group on ring-B $(\mathbf{2}, \mathbf{4}$, and 5$)$ showed more potent antiproliferative activity than the remaining compounds (Table 2). In addition, KB and KB-VIN cells displayed similar susceptibility to the tested chalcones. This finding suggested that the compounds might target specific proteins that are critical for cell growth and overexpressed in $\mathrm{KB}$ and KB-VIN cells.

Table 2. Antiproliferative activity of compounds 1-7 against other tumor cell lines.

\begin{tabular}{cccccc}
\hline \multirow{2}{*}{ Compounds } & A549 & MDA-MB-231 & MCF-7 & KB & KB-VIN \\
\hline $\mathbf{1}$ & $4.41 \pm 0.27$ & $3.82 \pm 0.24$ & $4.21 \pm 0.14$ & $4.47 \pm 0.07$ & $4.56 \pm 0.16$ \\
$\mathbf{2}$ & $0.52 \pm 0.01$ & $0.47 \pm 0.02$ & $0.68 \pm 0.04$ & $0.55 \pm 0.01$ & $0.84 \pm 0.00$ \\
$\mathbf{3}$ & $4.29 \pm 0.12$ & $3.94 \pm 0.30$ & $4.93 \pm 0.10$ & $4.20 \pm 0.41$ & $4.93 \pm 0.10$ \\
$\mathbf{4}$ & $2.97 \pm 0.35$ & $0.42 \pm 0.06$ & $1.49 \pm 0.21$ & $0.88 \pm 0.12$ & $2.45 \pm 0.38$ \\
$\mathbf{5}$ & $0.33 \pm 0.03$ & $0.46 \pm 0.01$ & $0.60 \pm 0.01$ & $0.58 \pm 0.02$ & $0.67 \pm 0.35$ \\
$\mathbf{6}$ & $3.71 \pm 0.07$ & $3.14 \pm 0.61$ & $4.07 \pm 0.14$ & $4.24 \pm 0.00$ & $4.33 \pm 0.12$ \\
$\mathbf{7}$ & $1.32 \pm 0.16$ & $0.62 \pm 0.01$ & $0.89 \pm 0.05$ & $4.61 \pm 0.10$ & $4.29 \pm 0.20$ \\
paclitaxel (nM) & $4.90 \pm 0.05$ & $6.78 \pm 0.20$ & $10.94 \pm 0.16$ & $5.24 \pm 0.08$ & $1843.5 \pm 29.9$ \\
\hline
\end{tabular}

${ }^{a}$ A549 (lung carcinoma), MDA-MB-231 (triple-negative breast cancer), MCF-7 (estrogen receptor-positive and HER2-negative breast cancer), KB (cervical cancer cell line HeLa derivative), KB-VIN (P-gp-overexpressing MDR subline of $\mathrm{KB}$ ). The values are average $\pm \mathrm{SD}$ of three independent experiment. ${ }^{b}$ Antiproliferative activity expressed as $\mathrm{IC}_{50}$ values for each cell line, the concentration of compound that caused $50 \%$ reduction relative to untreated cells determined by the SRB assay.

The resistance of tumor cells to drugs is always a severe obstacle to effective chemotherapy. As shown in Table 2, all tested compounds showed similar antiproliferative activity against $\mathrm{KB}$ and $\mathrm{KB}-\mathrm{VIN}$, suggesting that our compounds were not affected by the drug transporter P-gp. The most promising chalcone $\mathbf{5}$ was further tested against four kinds of taxane-resistant prostate cancer cell lines, DU145/TxR (docetaxel resistant DU145), DU145/TxR/CxR (docetaxel and cabazitaxel resistant DU145), PC-3/TxR (docetaxel resistant PC-3), and PC-3/TxR/CxR (docetaxel and cabazitaxel resistant PC-3) [21]. Chalcone 5 showed significant antiproliferative activity against these cells with $\mathrm{IC}_{50}$ values of 0.14-0.28 $\mu \mathrm{M}$ (Table 3). Taken together, the results suggesting that chalcone 5 potentially overcomes castration and taxane resistances. 
Table 3. Antiproliferative activity against docetaxel and cabazitaxel resistant prostate cancer cell lines DU145/TxR, DU145/TxR/CxR, PC-3/TxR and PC-3/TxR/CxR.

\begin{tabular}{|c|c|c|c|c|}
\hline \multirow[b]{2}{*}{ Compounds } & \multicolumn{4}{|c|}{ Cell Lines/IC $\mathrm{C}_{50}(\mu \mathrm{M})^{a}$} \\
\hline & DU145/TxR & DU145/TxR/CxR & PC-3/TxR & PC-3/TxR/CxR \\
\hline 5 & $0.14 \pm 0.03$ & $0.21 \pm 0.01$ & $0.28 \pm 0.08$ & $0.25 \pm 0.02$ \\
\hline
\end{tabular}

$\bar{a}$ The concentration of compound that caused $50 \%$ reduction of cell growth relative to untreated cells determined by cell counting. The values are average \pm SD of three independent experiment.

To estimate the in vivo antitumor effects of chalcone 5 , we tested it in a xenograft antitumor model assay using PC-3. As anticipated, the tumor growth was efficiently suppressed with both intraperitoneal and oral administration of 5 without significant weight loss compared with control (Figure 1). Notably, a dose of only $3 \mathrm{mg} / \mathrm{kg}$ was used in this study, even though many reported studies have used much larger doses of test compounds.
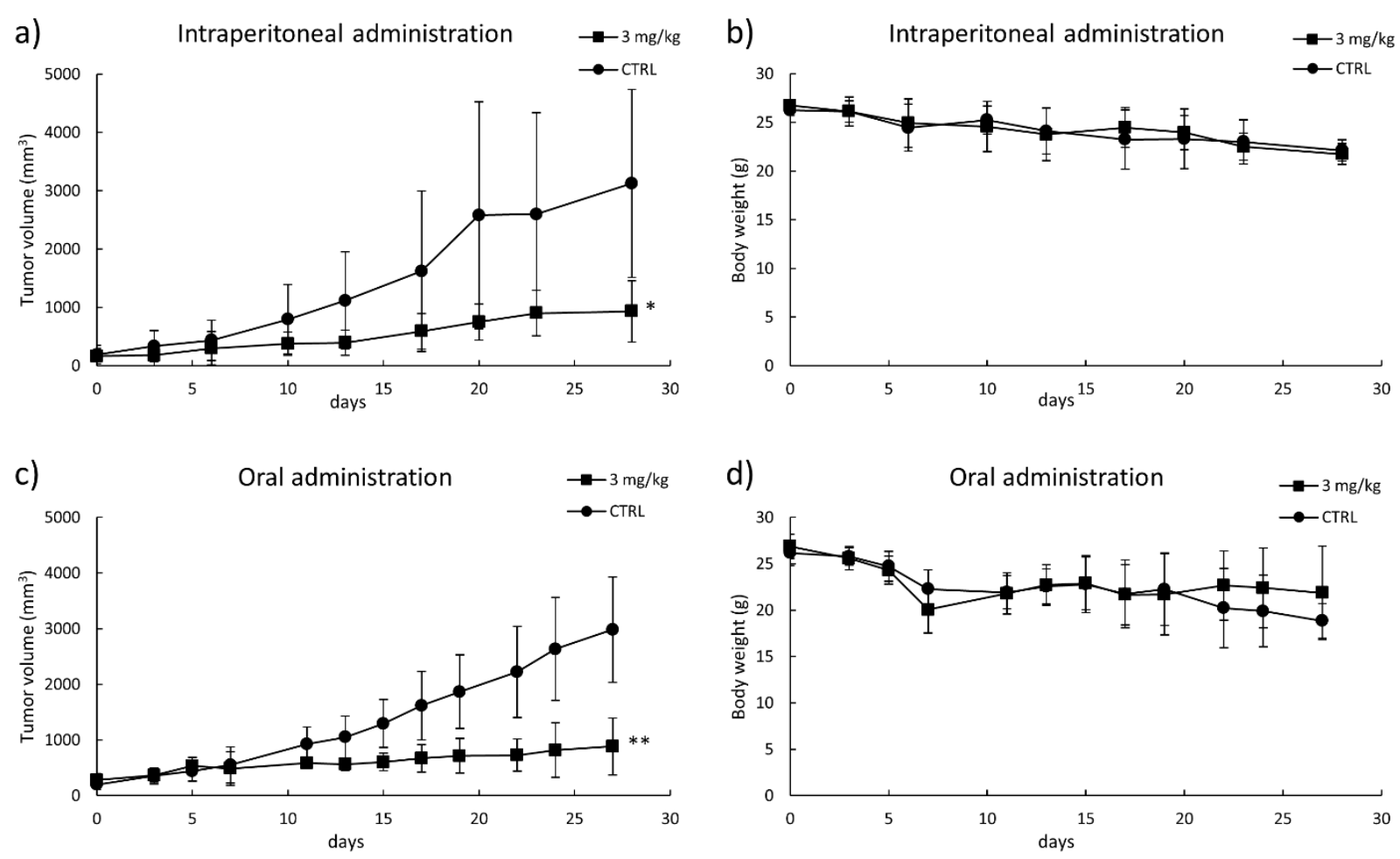

Figure 1. Effect of 5 against PC-3 tumor xenograft in C.B-17 scid mice. Compounds were intraperitoneally administrated at the indicated doses twice a week $(n=4)(\mathbf{a}, \mathbf{b})$ or orally administrated at the indicated doses three times a week $(n=5)$ $(\mathbf{c}, \mathbf{d})$. (a,c) Tumor volume in SCID mice during treatment with the compounds. (b,d) Average body weights of mice during treatment with the compounds. Data were presented as the average \pm SD. Significance was defined as ${ }^{*} p<0.05,{ }^{* *} p<0.005$ using Student's $t$ test.

The identification of target proteins is an important step in drug discovery and development. Accordingly, to study the mode of action of our new chalcones, we performed affinity labeling using a specifically designed and synthesized chemical probe (9) from the novel $\alpha-\mathrm{CF}_{3}$ chalcone 8. 4'-Amino-3,4-difluorochalcone [22] was selected for the introduction of propargyl group, which would work as a tether to immobilize on azide beads. Trifluoromethylation of $4^{\prime}$-amino-3,4-difluorochalcone gave 8 and propargylation of the amino group on 8 provided the target chalcone 9 (Scheme 2). The antiproliferative activities of 9 against DU145 and PC-3 were 1.43 and $1.34 \mu \mathrm{M}$, respectively (Table 4). Thus, chalcone 9 was 1.9-2.3 fold more potent than 8 ( $\mathrm{IC}_{50} 3.25 \mu \mathrm{M}$ for DU145 and $2.48 \mu \mathrm{M}$ for PC-3). In flow cytometric analysis, both 8 and $\mathbf{9}$ showed insignificant effects against KB-VIN despite 
using a three-fold concentration of their $\mathrm{IC}_{50}$ value. However, the treated MDA-MB-231 cells clearly showed accumulations of sub-G1 phase, a typical apoptotic pattern, and G2/M phase cells (Figure 2a).<smiles>Nc1ccc(C(=O)/C=C/c2ccc(F)c(F)c2)cc1</smiles><smiles>CC(C)C(=O)c1ccc(N)cc1</smiles><smiles>C#CCNc1ccc(C(=O)/C(=C\c2ccc(F)c(F)c2)C(F)(F)F)cc1</smiles>

Scheme 2. Synthesis of chemical probe for the identification of target proteins ${ }^{a}$. ${ }^{a}$ Reagents and conditions: (a) 1 Trifluoromethyl-1,2-benziodoxol-3(1H)-one, CuI, DMF, $80^{\circ} \mathrm{C}$. (b) 3-Bromo-1-propyne, $\mathrm{K}_{2} \mathrm{CO}_{3}, \mathrm{MeCN}, 80^{\circ} \mathrm{C}$.

Compared with the parent molecule 5 , chalcones 8 and $\mathbf{9}$ showed diminished antiproliferative effects against all tested human tumor cell lines (Tables 3 and 4). However, all three compounds displayed the same distribution pattern using flow cytometric analysis (Figure 2a), indicating the same intracellular targets. The tubulin polymerization inhibitor combretastatin A-4 (CA-4) was also evaluated in this study, since antiproliferative chalcones often target tubulin $[23,24]$. However, the effects of chalcone $\mathbf{5}$ on the cell cycle progression were clearly distinguishable from those of CA-4 (Figure 2a). Because G2/M phase accumulation often results from treatment with tubulin inhibitors [25], we evaluated the effects of chalcone 5 on tubulin polymerization and cell morphology by using immunocytochemical studies with an antibody to $\alpha$-tubulin (Figure $2 b$ ). The resulting confocal images indicated that chalcone 5 did not significantly affect either tubulin polymerization or cell morphology. The above cell-based mode of action studies suggested that chalcone 5 targets proteins related to the cell cycle progression in G2/M and apoptotic induction. Therefore, we next conducted affinity purification of chalcone 5-binding proteins using beads conjugated to compound 9 as a bait to identify the target proteins.

Table 4. Antiproliferative activity of compounds 8 and 9 against other tumor cell lines.

\begin{tabular}{|c|c|c|c|c|c|c|c|}
\hline Compounds & DU145 ${ }^{a}$ & PC $-3^{a}$ & $\mathrm{~A} 549^{b}$ & $\begin{array}{l}\text { ell Line }\left(\mathrm{IC}_{50} \mu \mathrm{M}\right) \\
\text { MDA-MB-231 }\end{array}$ & ${\mathrm{MCF}-7^{b}}^{b}$ & $\mathrm{~KB}^{b}$ & $\mathrm{~KB}-\mathrm{VIN}^{b}$ \\
\hline 8 & $3.25 \pm 0.90$ & $2.48 \pm 0.60$ & $4.10 \pm 0.40$ & $4.81 \pm 0.05$ & $4.89 \pm 0.05$ & $4.56 \pm 0.09$ & $4.98 \pm 0.01$ \\
\hline 9 & $1.43 \pm 0.13$ & $1.34 \pm 0.07$ & $4.20 \pm 0.01$ & $4.53 \pm 0.26$ & $4.88 \pm 0.05$ & $3.97 \pm 0.09$ & $4.51 \pm 0.06$ \\
\hline
\end{tabular}

${ }^{a}$ The concentration of compound that caused $50 \%$ reduction of cell growth relative to untreated cells determined by cell counting. The values are average $\pm \mathrm{SD}$ of three independent experiment. ${ }^{b}$ The concentration of compound that caused $50 \%$ reduction relative to untreated cells determined by the SRB assay.

Since 5 and 9 likely have identical intracellular mechanisms of action, affinity purification of the intracellular binding proteins of 5 was carried out using compound $\mathbf{9}$, the propargylated probe of $\mathbf{5}$. Compound $\mathbf{9}$ was immobilized on azide beads via a click reaction, and the obtained beads were reacted with PC-3 cell lysate followed by elution of binding proteins using SDS-PAGE sample buffer. The eluted fractions were separated by SDS-polyacrylamide gel electrophoresis (SDS-PAGE). Five main bands were detected by staining with Coumassie Brilliant Blue (CBB) dye, corresponding to proteins with molecular weights between 100 and $40 \mathrm{kDa}$ (Figure 3). Since all bands became undetectable when the lysate was preincubated with compound 5 as a competitive inhibitor, the bands were cut out and the proteins were digested by adding trypsin to the gel. The obtained trypsin-digested peptide sequences were identified by LC-MS/MS analysis. HSP90 and MICOS complex subunit MIC60 were detected from band No. 1. HSP70 (band No. 2), HSP60 (band No. 3), pyruvate kinase (band No. 3), T-complex protein 1 subunits (band No. 3), alpha-enolase 
(band No. 4), actin (band No. 5), and proliferation-associated protein 2G4 (band No. 5) were also identified. The list of identified proteins is shown in Supplementary Materials (Table S1). Heat shock proteins (HSPs) are well known not only as significant factors for cancer development but also targets for cancer therapy [26]. Glycolytic enzymes, including pyruvate kinase and alpha-enolase, are also related to tumor growth [27] and reported as diagnostic targets [28]. The unique target MIC60 plays an important role in the maintenance of mitochondrial crista structure [29] and PA2G4 isoforms display opposing functions, i.e., suppressive and promoting effects, in cancer [30]. Compound 5 might suppress cancer cell proliferation mainly by interacting with these proteins. Further studies are merited to demonstrate the clear target of chalcone 5 followed by the elucidation of druggable targets for drug development against CRPC. We are currently performing gene knockdown studies of the expressions of the identified proteins using siRNA in PC-3 cells.
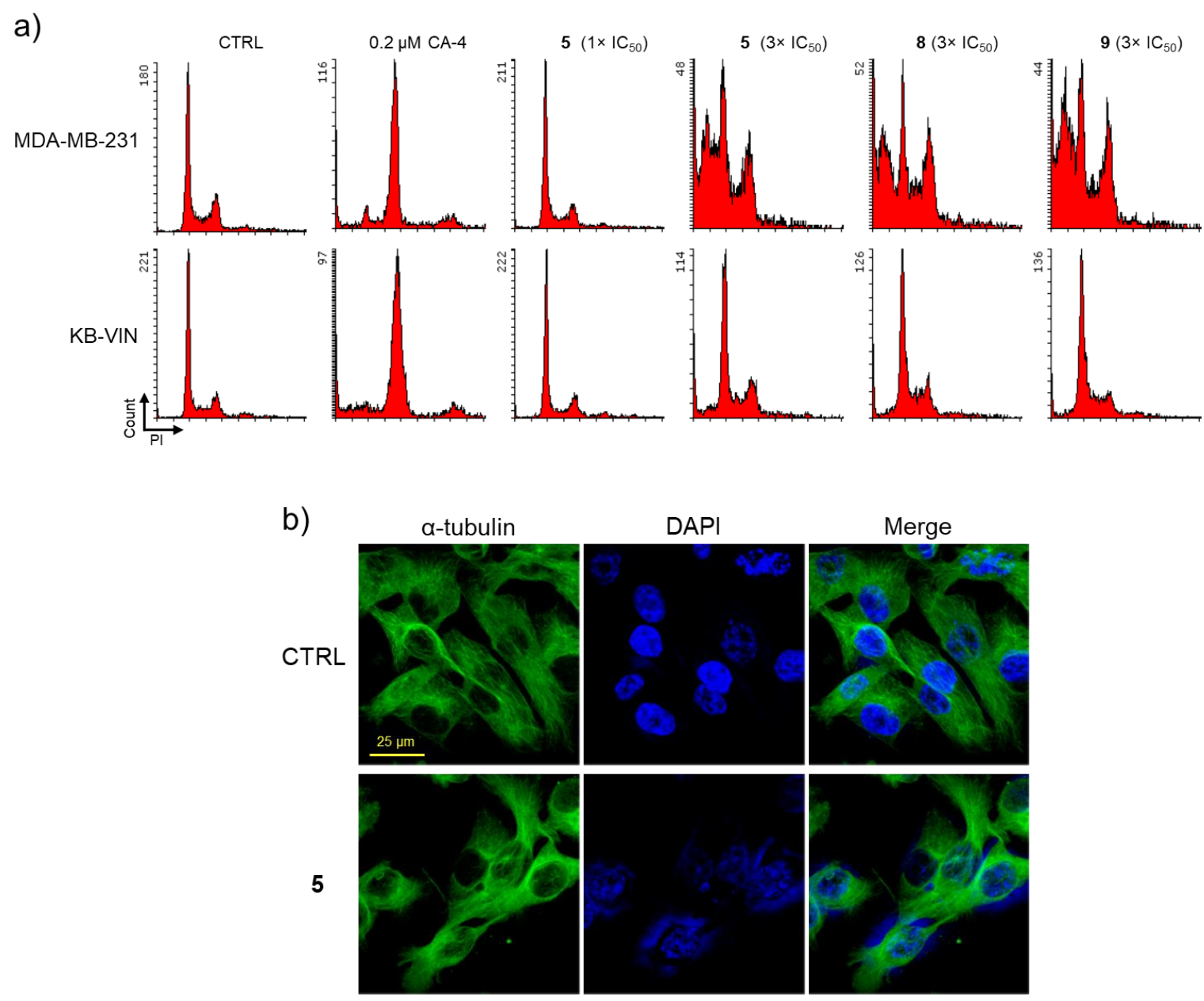

Figure 2. Effect of 5, 8, and 9 on cell cycle progression and of 5 on immunochemical staining. (a) Triple negative breast cancer MDA-MB-231 and multidrug-resistant KB-VIN cells were treated with 5, 8, and 9 for $24 \mathrm{~h}$. DMSO was used as a vehicle control (CTRL). 5 was used at $0.46 \mu \mathrm{M}\left(1 \times \mathrm{IC}_{50}\right)$ and $1.38 \mu \mathrm{M}\left(3 \times \mathrm{IC}_{50}\right)$ for MDA-MB-231, and $0.67 \mu \mathrm{M}\left(1 \times \mathrm{IC}_{50}\right)$ and $2.01 \mu \mathrm{M}\left(3 \times \mathrm{IC}_{50}\right)$ for $\mathrm{KB}-\mathrm{VIN}$, respectively. 8 was used at $14.4 \mu \mathrm{M}\left(3 \times \mathrm{IC}_{50}\right)$ for MDA-MB-231, and $14.9 \mu \mathrm{M}\left(3 \times \mathrm{IC}_{50}\right)$ for KB-VIN, respectively. 9 was used at $13.6 \mu \mathrm{M}\left(3 \times \mathrm{IC}_{50}\right)$ for MDA-MB-231, and $13.5 \mu \mathrm{M}\left(3 \times \mathrm{IC}_{50}\right)$ for KB-VIN, respectively. Combretastatin A-4 (CA-4) was used at $0.2 \mu \mathrm{M}\left(3 \times \mathrm{IC}_{50}\right)$. Tubulin polymerization inhibitor CA-4 was used as a control for mitotic inhibitor (G2/M). Cell cycle distributions of treated cells were analyzed by flow cytometry (LSRFortessa operated by FACS Diva software, BD Bioscience) after staining with propidium iodide (PI) in the presence of RNase. (b) MDA-MB-231 cells were seeded in an 8-well chamber slide $\left(2.4 \times 10^{4}\right.$ cells/well) $24 \mathrm{~h}$ prior to treatment with 5 for $24 \mathrm{~h}$ at $1.38 \mu \mathrm{M}$ $\left(3 \times \mathrm{IC}_{50}\right) \cdot 0.02 \%$ DMSO was used for negative control. Fixed cells were labeled with antibodies to $\alpha$-tubulin (green) and DAPI for DNA (blue). 14-18 confocal images were stacked and merged. Bar, $25 \mu \mathrm{m}$. 


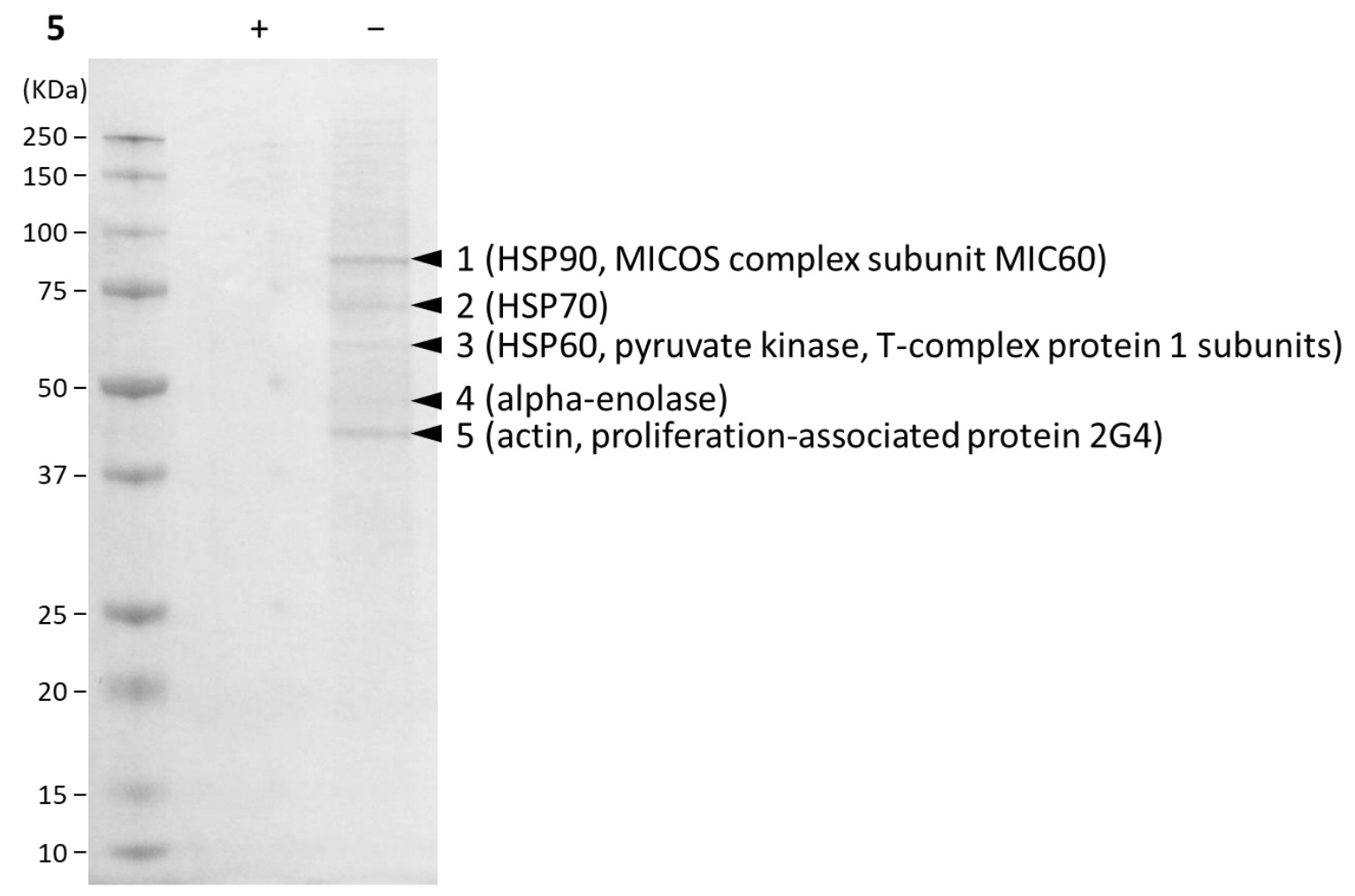

Figure 3. Target identification of compound 5. PC-3 cell lysate was preincubated with (+) or without (-) compound 5. Affinity purification of binding proteins was performed using compound 9-immobilized beads. Five main bands (No. 1 to 5 ) were detected by CBB staining after SDS-PAGE.

\section{Materials and Methods}

\subsection{Chemistry}

All solvents and chemicals were used as purchased without further purification. The progress of reactions was monitored on Merck Millipore precoated silica gel glass plates (TLC Silica gel 60 F254). Column chromatography was performed with Kanto chemical silica gel $60 \mathrm{~N}$ (spherical, neutral) or preparative TLC was carried out with Merck Millipore precoated silica gel glass plates (PLC Silica gel $60 \mathrm{~F} 254,1 \mathrm{~mm}$ ) for the purification of synthetic compounds. ${ }^{1} \mathrm{H}$ and ${ }^{13} \mathrm{C}$ NMR spectra were recorded on JEOL JNM-ECA 600 or JNM-ECS 400 using $\mathrm{CDCl}_{3}$ as solvent and referenced to TMS or residual solvent peak. Chemical shifts $\delta$ are reported in ppm. Mass spectrometric analysis were performed using JEOL JMS-700 Mstation or JMS-T100TD. UV spectra were recorded on a Tecan SPARK $10 \mathrm{M}$ in $\mathrm{MeCN}-\mathrm{H}_{2} \mathrm{O}$ (1:1). IR spectra were measured on Shimadzu IRSprit in neat. Melting points were measured on an AS ONE ATM-02. The purity of all compounds was determined as $>95 \%$ by ${ }^{1} \mathrm{H}$ NMR.

\subsection{General Procedures for Chalcones}

To a solution of $1^{\prime}$-acetonaphthone $(120 \mathrm{mg}, 0.70 \mathrm{mmol})$ and 3,4-difluorobenzaldehyde $(100 \mathrm{mg}, 0.70 \mathrm{mmol})$ in $\mathrm{EtOH}(1.0 \mathrm{~mL})$ was added $40 \%$ aqueous $\mathrm{KOH}(0.5 \mathrm{~mL})$, and the mixture was stirred at room temperature. After the reaction was complete, ice-water was added to the reaction mixture, which was then neutralized with $1 \mathrm{~N} \mathrm{HCl}$. The mixture was extracted with EtOAc and the resultant organic phase was washed with brine, dried over $\mathrm{MgSO}_{4}$, and concentrated in vacuo. The residue was purified by column chromatography on $\mathrm{SiO}_{2}$, eluting with hexane-EtOAc (15:1) to give (E)-3-(3,4-difluorophenyl)-1-(naphthalen1-yl)prop-2-en-1-one (172 mg, $0.58 \mathrm{mmol}$ ) in $83 \%$ yield as a colorless solid. All chalcones were produced by the same procedure. 
3.2.1. (E)-3-(3,4-difluorophenyl)-1-(naphthalen-1-yl)prop-2-en-1-one (10)

Rf 0.25 (hexane/EtOAc, 10:1); $\mathrm{mp} 81^{\circ} \mathrm{C}$; UV (MeCN/ $\left.\mathrm{H}_{2} \mathrm{O}, 1: 1\right) \lambda_{\max }$ (nm) 220, 302; IR (neat) $v_{\max }\left(\mathrm{cm}^{-1}\right) 3050,1652,1583,1516,1271,1097,980,796,772 ;{ }^{1} \mathrm{H}$ NMR $(600 \mathrm{MHz}$, $\left.\mathrm{CDCl}_{3}\right): \delta 8.33(\mathrm{~d}, J=7.8 \mathrm{~Hz}, 1 \mathrm{H}), 8.01(\mathrm{~d}, J=8.4 \mathrm{~Hz}, 1 \mathrm{H}), 7.92(\mathrm{~d}, J=6.6 \mathrm{~Hz}, 1 \mathrm{H}), 7.77(\mathrm{~d}$, $J=6.6 \mathrm{~Hz}, 1 \mathrm{H}), 7.59-7.51(\mathrm{~m}, 4 \mathrm{H}), 7.40(\mathrm{ddd}, J=10.2,8.4,1.8 \mathrm{~Hz}, 1 \mathrm{H}), 7.30(\mathrm{ddd}, J=6.6,4.2$, $1.8 \mathrm{~Hz}, 1 \mathrm{H}), 7.22(\mathrm{~d}, J=16.2 \mathrm{~Hz}, 1 \mathrm{H}), 7.19(\mathrm{~m} 1 \mathrm{H}) ;{ }^{13} \mathrm{C} \mathrm{NMR}\left(150 \mathrm{MHz}, \mathrm{CDCl}_{3}\right): \delta 194.9$, $151.7(\mathrm{dd}, J=252.8,12.9 \mathrm{~Hz}), 150.7(\mathrm{dd}, J=248.6,12.9 \mathrm{~Hz}), 143.2,136.7,133.9,132.0,131.9$ $(\mathrm{dd}, J=4.4,4.4 \mathrm{~Hz}), 130.4,128.5,127.8,127.6,127.3,126.6,125.5,125.3(\mathrm{dd}, J=5.7,2.9 \mathrm{~Hz})$, $124.5,117.9(\mathrm{~d}, J=18.6 \mathrm{~Hz}), 116.6(\mathrm{~d}, J=18.6 \mathrm{~Hz})$; HRMS $(\mathrm{FAB}) \mathrm{m} / \mathrm{z}:[\mathrm{M}+\mathrm{H}]^{+}$calcd for $\mathrm{C}_{19} \mathrm{H}_{13} \mathrm{~F}_{2} \mathrm{O} 295.0934$, found 295.0941.

\subsection{2. (E)-3-(benzo[b]thiophen-3-yl)-1-phenylprop-2-en-1-one (11)}

The chalcone was prepared from acetophenone and benzo[b]thiophene-3-carboxaldehyde as a yellow solid. Yield: 70\%. Rf 0.3 (hexane/EtOAc, 10:1); mp 94-95 ${ }^{\circ} \mathrm{C}$; $\mathrm{UV}\left(\mathrm{MeCN} / \mathrm{H}_{2} \mathrm{O}\right.$, 1:1) $\lambda_{\max }(\mathrm{nm}) 226,266,356$; IR (neat) $v_{\max }\left(\mathrm{cm}^{-1}\right) 3091,3055,1653,1586,1575,1495,1367$, 1202, 1010, 971, 780, 729, 690; ${ }^{1} \mathrm{H}$ NMR $\left(400 \mathrm{MHz} \mathrm{CDCl}_{3}\right): \delta 8.15-8.05(\mathrm{~m} 4 \mathrm{H}), 7.93(\mathrm{~s}, 1 \mathrm{H})$, $7.92(\mathrm{~d}, J=7.2 \mathrm{~Hz}, 1 \mathrm{H}), 7.66(\mathrm{~d}, J=16.0 \mathrm{~Hz}, 1 \mathrm{H}), 7.61(\mathrm{~m}, 1 \mathrm{H}), 7.56-7.49(\mathrm{~m}, 3 \mathrm{H}), 7.44(\mathrm{dd}$, $J=7.2,7.2 \mathrm{~Hz}, 1 \mathrm{H}) ;{ }^{13} \mathrm{C}$ NMR $\left(150 \mathrm{MHz}, \mathrm{CDCl}_{3}\right): \delta 190.4,140.6,138.2,137.3,136.4,132.8$, $132.3,128.7,128.7,128.5,125.2,125.1,123.1,122.4,122.2$; HRMS (FAB) $m / z:[\mathrm{M}+\mathrm{H}]^{+}$calcd for $\mathrm{C}_{17} \mathrm{H}_{13} \mathrm{OS} 265.0687$, found 265.0684 .

\subsection{General Procedures for a-CF 3 Chalcones}

To a mixture of 1-trifluoromethyl-1,2-benziodoxol-3(1H)-one (170 mg, $0.22 \mathrm{mmol})$ and copper iodide $(2.7 \mathrm{mg}, 0.014 \mathrm{mmol})$ was added chalcone $(30 \mathrm{mg}, 0.14 \mathrm{mmol})$ in DMF $(0.2 \mathrm{~mL})$ under $\mathrm{N}_{2}$ atmosphere and the mixture was stirred at $80^{\circ} \mathrm{C}$. After the reaction was complete, the mixture was concentrated. The residue was purified by column chromatography on silica gel, eluting with hexane-EtOAc (50:1) to give (E)-1,3-diphenyl-2-(trifluoromethyl)prop2-en-1-one (1) [9] (9.4 mg, $0.034 \mathrm{mmol}$ ) in $24 \%$ yield as a pale, yellow oil. $\alpha-\mathrm{CF}_{3}$ chalcones $2-8$ were produced by the same procedure.

\subsection{1. (E)-3-(4-nitrophenyl)-1-phenyl-2-(trifluoromethyl)prop-2-en-1-one (2)}

Compound 2 was prepared from 4-nitrochalcone [10] as a colorless solid. Yield: $9 \%$. Rf 0.25 (hexane/EtOAc, 10:1); mp 119-120 ${ }^{\circ} \mathrm{C}$; UV (MeCN/ $\left.\mathrm{H}_{2} \mathrm{O}, 1: 1\right) \lambda_{\max }$ (nm) 262; IR (neat) $v_{\max }\left(\mathrm{cm}^{-1}\right) 3079,2933,2859,1667,1596,1520,1346,1267,917,824,687 ;{ }^{1} \mathrm{H} \mathrm{NMR}$ $\left(600 \mathrm{MHz}, \mathrm{CDCl}_{3}\right): \delta 8.06(\mathrm{~d}, J=8.4 \mathrm{~Hz}, 2 \mathrm{H}), 7.87(\mathrm{dd}, J=8.4,1.2 \mathrm{~Hz}, 2 \mathrm{H}), 7.56(\mathrm{tt}, J=7.2$, $1.2 \mathrm{~Hz}, 1 \mathrm{H}), 7.54(\mathrm{~s}, 1 \mathrm{H}), 7.43(\mathrm{~d}, J=9.0 \mathrm{~Hz}, 2 \mathrm{H}), 7.40(\mathrm{t}, J=7.8 \mathrm{~Hz}, 2 \mathrm{H}) ;{ }^{13} \mathrm{C}$ NMR $(125 \mathrm{MHz}$, $\left.\mathrm{CDCl}_{3}\right): \delta 192.7,148.3,138.2,135.0,134.9,134.1(\mathrm{q}, J=5.9 \mathrm{~Hz}), 130.1,129.6,129.1,123.9$; HRMS (FAB) $m / z:[\mathrm{M}+\mathrm{H}]^{+}$calcd for $\mathrm{C}_{16} \mathrm{H}_{11} \mathrm{~F}_{3} \mathrm{NO}_{3} 322.0691$, found 322.0678 .

\subsection{2. (E)-3-[4-(dimethylamino)phenyl]-1-phenyl-2-(trifluoromethyl)prop-2-en-1-one (3)}

Compound 3 was prepared from 4-(dimethylamino)chalcone [11] as a yellow oil. Yield: $26 \%$. Rf 0.2 (hexane/EtOAc, 10:1); UV (MeCN/ $\left.\mathrm{H}_{2} \mathrm{O}, 1: 1\right) \lambda_{\max }(\mathrm{nm}) 254,336,398$; IR (neat) $v_{\max }\left(\mathrm{cm}^{-1}\right) 3060,2909,2861,2816,2359,1660,1593,1526,1278,1147,1108,814,696$, $687{ }^{1} \mathrm{H}$ NMR $\left(400 \mathrm{MHz}, \mathrm{CDCl}_{3}\right): \delta 7.96(\mathrm{dd}, J=8.4,1.2 \mathrm{~Hz}, 2 \mathrm{H}), 7.52(\mathrm{tt}, J=7.2,1.2 \mathrm{~Hz}, 1 \mathrm{H})$, $7.39(\mathrm{t}, J=8.4 \mathrm{~Hz}, 2 \mathrm{H}), 7.34(\mathrm{~d}, J=1.2 \mathrm{~Hz}, 1 \mathrm{H}), 7.11(\mathrm{~d}, J=9.2 \mathrm{~Hz}, 2 \mathrm{H}), 6.44(\mathrm{~d}, J=9.2 \mathrm{~Hz}$, 2H), $2.91(\mathrm{~s}, 6 \mathrm{H}) ;{ }^{13} \mathrm{C}$ NMR (100 MHz, CDCl 3 ): $\delta 193.9,151.3,137.3(\mathrm{q}, J=5.7 \mathrm{~Hz}), 136.0$, 134.0, 131.8, 129.7, 128.8, 119.3, 111.4, 39.9; HRMS (FAB) $m / z:[\mathrm{M}+\mathrm{H}]^{+}$calcd for $\mathrm{C}_{18} \mathrm{H}_{17} \mathrm{~F}_{3} \mathrm{NO}$ 320.1262 , found 320.1262 .

3.3.3. (E)-1-phenyl-2-(trifluoromethyl)-3-(4-(trifluoromethyl)phenyl)prop-2-en-1-one (4)

Compound 4 was prepared from 4-(trifluoromethyl)chalcone [12] as a pale-yellow oil. Yield: 9\%. Rf 0.4 (hexane/EtOAc, 10:1); UV (MeCN/ $\left.\mathrm{H}_{2} \mathrm{O}, 1: 1\right) \lambda_{\max }$ (nm) 254; IR (neat) $v_{\max }\left(\mathrm{cm}^{-1}\right) 3067,2928,2853,1670,1323,1269,1163,1067,834,687 ;{ }^{1} \mathrm{H}$ NMR $(400 \mathrm{MHz}$, $\left.\mathrm{CDCl}_{3}\right): \delta 7.89(\mathrm{dd}, J=8.4,1.2 \mathrm{~Hz}, 2 \mathrm{H}), 7.56(\mathrm{tt}, J=7.2,1.2 \mathrm{~Hz}, 1 \mathrm{H}), 7.51(\mathrm{~s}, 1 \mathrm{H}), 7.47(\mathrm{~d}$, 
$J=8.4 \mathrm{~Hz}, 1 \mathrm{H}, \mathrm{H}-\mathrm{Ar}), 7.42-7.36(\mathrm{~m}, 4 \mathrm{H}) ;{ }^{13} \mathrm{C} \mathrm{NMR}\left(150 \mathrm{MHz}, \mathrm{CDCl}_{3}\right): \delta 192.0,135.4,135.1$, $135.0(\mathrm{q}, J=5.7 \mathrm{~Hz}), 134.7,131.8(\mathrm{q}, J=33.0 \mathrm{~Hz}), 131.4(\mathrm{q}, J=30.2 \mathrm{~Hz}), 129.6,129.6,129.0$, $125.8(\mathrm{q}, J=4.2 \mathrm{~Hz}), 123.5(\mathrm{q}, J=270.0 \mathrm{~Hz}), 121.9(\mathrm{q}, J=274.4 \mathrm{~Hz}) ; \mathrm{HRMS}(\mathrm{FAB}) \mathrm{m} / z:[\mathrm{M}+\mathrm{H}]^{+}$ calcd for $\mathrm{C}_{17} \mathrm{H}_{11} \mathrm{~F}_{6} \mathrm{O} 345.0714$, found 345.0716.

3.3.4. (E)-3-(3,4-difluorophenyl)-1-phenyl-2-(trifluoromethyl)prop-2-en-1-one (5)

Compound 5 was prepared from 3,4-diifluorochalcone [13] as a colorless oil. Yield: $29 \%$. Rf 0.3 (hexane/EtOAc, 10:1); UV (MeCN/ $\left.\mathrm{H}_{2} \mathrm{O}, 1: 1\right) \lambda_{\max }(\mathrm{nm}) 254$; IR (neat) $v_{\max }$ $\left(\mathrm{cm}^{-1}\right)$ 3064, 2918, 1667, 1517, 1263, 1119, 917, 686; ${ }^{1} \mathrm{H}$ NMR $\left(600 \mathrm{MHz}, \mathrm{CDCl}_{3}\right): \delta 7.89(\mathrm{dd}$, $J=8.4,1.2 \mathrm{~Hz}, 2 \mathrm{H}), 7.57(\mathrm{t}, J=7.2 \mathrm{~Hz}, 1 \mathrm{H}), 8.16(\mathrm{t}, J=7.8 \mathrm{~Hz}, 2 \mathrm{H}), 7.39(\mathrm{~s}, 1 \mathrm{H}), 7.10-7.07(\mathrm{~m}$, 1H), 7.03-6.98 (m, 2H); $\left.{ }^{13} \mathrm{C} \mathrm{NMR} \mathrm{(150} \mathrm{MHz,} \mathrm{CDCl}_{3}\right): \delta 192.1,151.2(\mathrm{dd}, J=252.8,12.9 \mathrm{~Hz})$, $150.1(\mathrm{dd}, J=249.9,12.9 \mathrm{~Hz}), 135.1,134.8,134.4(\mathrm{q}, J=5.7 \mathrm{~Hz}), 130.1(\mathrm{q}, J=30.2 \mathrm{~Hz}), 129.8$, 129.6, $129.0,126.2,122.0(\mathrm{q}, J=273.0 \mathrm{~Hz}), 118.4(\mathrm{~d}, J=18.6 \mathrm{~Hz}), 117.9(\mathrm{~d}, J=18.8 \mathrm{~Hz})$; HRMS (FAB) $m / z:[\mathrm{M}+\mathrm{H}]^{+}$calcd for $\mathrm{C}_{16} \mathrm{H}_{10} \mathrm{~F}_{5} \mathrm{O} 313.0652$, found 313.0653.

3.3.5. (E)-3-(3,4-difluorophenyl)-1-(naphthalen-1-yl)-2-(trifluoromethyl)prop-2-en-1-one (6)

Compound 6 was prepared from (E)-3-(3,4-difluorophenyl)-1-(naphthalen-1-yl)prop2-en-1-one 10 as a yellow solid. Yield: $16 \%$. Rf 0.35 (hexane/EtOAc, 10:1); mp 71-72 ${ }^{\circ} \mathrm{C}$; UV (MeCN/ $\left.\mathrm{H}_{2} \mathrm{O}, 1: 1\right) \lambda_{\max }(\mathrm{nm}) 212,332$; IR (neat) $\nu_{\max }\left(\mathrm{cm}^{-1}\right) 3087,3063,2919,1655$, 1516, 1272, 1243, 1229, 1122, 1110, 1001, 920, 776; ${ }^{1} \mathrm{H}$ NMR (600 MHz, $\left.\mathrm{CDCl}_{3}\right): \delta 9.05(\mathrm{~d}$, $J=9.0 \mathrm{~Hz}, 1 \mathrm{H}), 8.01(\mathrm{~d}, J=8.4 \mathrm{~Hz}, 1 \mathrm{H}), 7.92(\mathrm{~d}, J=7.2 \mathrm{~Hz}, 1 \mathrm{H}), 7.88(\mathrm{~d}, J=7,8 \mathrm{~Hz}, 1 \mathrm{H}), 7.73$ $(\mathrm{t}, J=7.8 \mathrm{~Hz}, 1 \mathrm{H}), 7.60(\mathrm{t}, J=7.2 \mathrm{~Hz}, 1 \mathrm{H}), 7.43(\mathrm{~s}, 1 \mathrm{H}), 7.38(\mathrm{t}, J=7.8 \mathrm{~Hz}, 1 \mathrm{H}), 7.12-7.09(\mathrm{~m}$, 1H), 7.04-7.01 (m, 1H), 6.87-6.83 (m, 1H); ${ }^{13} \mathrm{C} \mathrm{NMR}\left(150 \mathrm{MHz}, \mathrm{CDCl}_{3}\right): \delta 193.3,151.0(\mathrm{dd}$, $J=252.8,12.9 \mathrm{~Hz}), 150.1(\mathrm{dd}, J=248.6,12.9 \mathrm{~Hz}), 135.6,135.2(\mathrm{q}, J=5.7 \mathrm{~Hz}), 133.9,132.7$, $132.2(\mathrm{q}, J=30.2 \mathrm{~Hz}), 132.0,130.9,129.4,129.3,128.7,127.0,126.0,125.4,124.2,122.2(\mathrm{q}$, $J=272.9 \mathrm{~Hz}), 118.3(\mathrm{~d}, J=18.6 \mathrm{~Hz}), 117.6(\mathrm{~d}, J=17.3 \mathrm{~Hz}) ; \mathrm{HRMS}(\mathrm{FAB}) \mathrm{m} / z:[\mathrm{M}+\mathrm{H}]^{+}$calcd for $\mathrm{C}_{20} \mathrm{H}_{12} \mathrm{~F}_{5} \mathrm{O} 363.0808$, found 363.0793 .

3.3.6. (E)-3-(benzo[b]thiophen-3-yl)-1-phenyl-2-(trifluoromethyl)prop-2-en-1-one (7)

Compound 7 was prepared from (E)-3-(benzo[b]thiophen-3-yl)-1-phenylprop-2-en-1one 11 as a colorless oil. Yield: 20\%. Rf 0.4 (hexane/EtOAc, 10:1); $\mathrm{UV}\left(\mathrm{MeCN} / \mathrm{H}_{2} \mathrm{O}, 1: 1\right)$ $\lambda_{\max }(\mathrm{nm}) 228,266,316$; IR (neat) $v_{\max }\left(\mathrm{cm}^{-1}\right)$ 3064, 3031, 1663, 1335, 1272, 1169, 1120, 910, 757, 732, 686, 589; ${ }^{1} \mathrm{H}$ NMR (600 MHz, $\left.\mathrm{CDCl}_{3}\right): \delta 7.90-7.87(\mathrm{~m}, 3 \mathrm{H}), 7.78(\mathrm{~d}, J=7.8 \mathrm{~Hz}$, $1 \mathrm{H}), 7.74(\mathrm{~s}, 1 \mathrm{H}), 7.48(\mathrm{dt}, J=7.2,1.2 \mathrm{~Hz}, 2 \mathrm{H}), 7.40(\mathrm{t}, J=7.8 \mathrm{~Hz}, 1 \mathrm{H}), 7.37(\mathrm{~s}, 1 \mathrm{H}), 7.33(\mathrm{t}$, $J=7.2 \mathrm{~Hz}, 2 \mathrm{H}) ;{ }^{13} \mathrm{C} \mathrm{NMR}\left(150 \mathrm{MHz}, \mathrm{CDCl}_{3}\right): \delta 192.8,139.5,137.6,135.2,134.4,129.6,129.4$, $128.8,128.1(\mathrm{q}, J=5.7 \mathrm{~Hz}), 127.6,125.2,125.0,122.9,121.2 ; \mathrm{HRMS}(\mathrm{FAB}) \mathrm{m} / z:[\mathrm{M}+\mathrm{H}]^{+}$calcd for $\mathrm{C}_{18} \mathrm{H}_{12} \mathrm{~F}_{3} \mathrm{OS}$ 333.0561, found 333.0574.

3.3.7. (E)-1-(4-aminophenyl)-3-(3,4-difluorophenyl)-2-(trifluoromethyl)prop-2-en-1-one (8)

Compound 8 was prepared from (E)-1-(4-aminophenyl)-3-(3,4-difluorophenyl)prop2-en-1-one [19] as a yellow solid. Yield: $53 \%$. Rf 0.2 (hexane/EtOAc, 3:1); mp $94-95^{\circ} \mathrm{C}$; UV (MeCN/ $\left.\mathrm{H}_{2} \mathrm{O}, 1: 1\right) \lambda_{\max }(\mathrm{nm}) 248,350$; IR (neat) $\gamma_{\max }\left(\mathrm{cm}^{-1}\right) 3422,3345,3232,3963$, 2919, 1636, 1580, 1558, 1523, 1300, 1256, 1173, 1116; $\left.{ }^{1} \mathrm{H} \mathrm{NMR} \mathrm{(400} \mathrm{MHz,} \mathrm{CDCl}_{3}\right): \delta 7.73$ $(\mathrm{d}, J=8.8 \mathrm{~Hz}, 2 \mathrm{H}), 7.15-7.10(\mathrm{~m}, 1 \mathrm{H}), 7.07-6.97(\mathrm{~m}, 1 \mathrm{H}), 6.56(\mathrm{~d}, J=8.8 \mathrm{~Hz}, 2 \mathrm{H}), 4.27$ (brs, $2 \mathrm{H}) ;{ }^{13} \mathrm{C} \mathrm{NMR}\left(150 \mathrm{MHz}, \mathrm{CDCl}_{3}\right): \delta 189.4,152.7,151.0(\mathrm{dd}, J=252.8,12.9 \mathrm{~Hz}), 149.1(\mathrm{dd}$, $J=248.4,12.9 \mathrm{~Hz}), 132.9(\mathrm{q}, J=4.4 \mathrm{~Hz}), 132.5,130.6(\mathrm{q}, J=30.2 \mathrm{~Hz}), 129.4,126.2,125.5$, $122.2(\mathrm{q}, J=273.0 \mathrm{~Hz}), 118.3(\mathrm{~d}, J=18.8 \mathrm{~Hz}), 117.7(\mathrm{~d}, J=17.1 \mathrm{~Hz}), 113.9$; HRMS (FAB) $m / z$ : $[\mathrm{M}+\mathrm{H}]^{+}$calcd for $\mathrm{C}_{16} \mathrm{H}_{11} \mathrm{~F}_{5} \mathrm{NO} 328.0761$, found 328.0750.

3.4. (E)-3-(3,4-difluorophenyl)-1-[4-(prop-2-yn-1-ylamino)phenyl]-2-(trifluoromethyl)prop-2-en1-one (9)

To a solution of compound 8 (67 mg, $0.2 \mathrm{mmol})$ in $\mathrm{MeCN}(0.2 \mathrm{~mL})$ were added 3bromo-1-propyne $(23 \mu \mathrm{L}, 0.3 \mathrm{mmol})$ and $\mathrm{K}_{2} \mathrm{CO}_{3}(85 \mathrm{mg}, 0.6 \mathrm{mmol})$ and the mixture was stirred at $80^{\circ} \mathrm{C}$. After stirring overnight, the reaction mixture was concentrated. The residue 
was purified by preparative TLC eluting with toluene-EtOAc (10:1) to give compound 9 (13.4 mg, $0.037 \mathrm{mmol}$ ) in 18\% yield as a yellow oil. Rf 0.35 (hexane/EtOAc, 3:1); UV $\left(\mathrm{MeCN} / \mathrm{H}_{2} \mathrm{O}, 1: 1\right) \lambda_{\max }(\mathrm{nm}) 248,354$; IR (neat) $v_{\max }\left(\mathrm{cm}^{-1}\right) 3369,3306,3058,2922,1585$, 1516, 1257, 1173, 1115, 915, 833; ${ }^{1} \mathrm{H}$ NMR $\left(400 \mathrm{MHz}, \mathrm{CDCl}_{3}\right): \delta 7.79(\mathrm{~d}, J=8.4 \mathrm{~Hz}, 2 \mathrm{H})$, 7.19-7.11 (m, 2H), 7.08-6.98 (m, 2H), $6.58(\mathrm{~d}, J=8.4 \mathrm{~Hz}, 2 \mathrm{H}), 4.56(\mathrm{t}, J=5.6 \mathrm{~Hz}, 1 \mathrm{H}), 3.98$ $(\mathrm{dd}, J=5.6,2.4 \mathrm{~Hz}, 2 \mathrm{H}), 2.27(\mathrm{t}, J=2.4 \mathrm{~Hz}, 1 \mathrm{H}) ;{ }^{13} \mathrm{C} \mathrm{NMR}\left(150 \mathrm{MHz}, \mathrm{CDCl}_{3}\right): \delta 189.5,152.1$, $151.0(\mathrm{dd}, J=252.8,12.9 \mathrm{~Hz}), 150.1(\mathrm{dd}, J=248.4,12.9 \mathrm{~Hz}), 132.9(\mathrm{q}, J=5.9 \mathrm{~Hz}), 132.3$, $130.6(\mathrm{q}, J=30.2 \mathrm{~Hz}), 129.4,126.2,125.5,122.2(\mathrm{q}, J=272.9 \mathrm{~Hz}), 118.3(\mathrm{~d}, J=18.8 \mathrm{~Hz}), 117.7$ $(\mathrm{d}, J=18.8 \mathrm{~Hz}), 112.4,79.2,72.2,32.9$; HRMS $(\mathrm{FAB}) \mathrm{m} / z:[\mathrm{M}+\mathrm{H}]^{+}$calcd for $\mathrm{C}_{19} \mathrm{H}_{13} \mathrm{~F}_{5} \mathrm{NO}$ 366.0917, found 366.0913.

\subsection{Cell Proliferation Assay Using PCa Cells}

DU145 cells $\left(5 \times 10^{4}\right)$ were seeded on 12-well plates (2-layer chambers) with DMEM including 5\% charcoal-stripped fetal calf serum (CCS) (HyClone Laboratories, Logan, UT, USA). PC-3 cells $\left(5 \times 10^{4}\right)$ were seeded on 12-well plates (2-layer chambers) with RPMI-1640 including 5\% charcoal-stripped fetal calf serum (CCS) (HyClone Laboratories, Logan, UT, USA). After $24 \mathrm{~h}$, cells were treated with compounds and cultured for 4 days. Medium was replaced once, at day 2 of treatment. To determine cell proliferation, cells were trypsinized and counted in triplicate using a hemocytometer. The data represent the means \pm SD of three replicates.

\subsection{Antiproliferative Activity against Non-Prostate Cancer Cell Lines}

Assay was performed as described previously [20]. Briefly, freshly trypsinized cell suspensions were seeded on 96-well microtiter plates at densities of 4000-11,000 cells per well with compounds. After $72 \mathrm{~h}$ in culture with test compounds, attached cells were fixed in $10 \%$ trichloroacetic acid and then stained with $0.04 \%$ sulforhodamine B. The absorbance at $515 \mathrm{~nm}$ was measured using a microplate reader (ELx800, BioTek, Winooski, VT, USA) operated by Gen5 software (BioTek, Winooski, VT, USA) after solubilizing the bound dye with $10 \mathrm{mM}$ Tris base. The mean $\mathrm{IC}_{50}$ is the average from at least three independent experiments in duplicate.

\subsection{Xenograft Model in Mice}

Six-week-old male severe combined immunodeficient (SCID) mice were purchased from CLEA Japan (Tokyo, Japan). After an acclimatization period, $2 \times 10^{6} \mathrm{PC}-3$ cells were implanted with 50\% Matrigel (Corning, NY, USA) in the dorsal subcutaneous region of the SCID mice. When the tumors were large enough for their length to be measured, the mice were divided into two groups (five mice in each group) so that the mean tumor size in each group was approximately equal. For the intraperitoneal administration, chalcone $\mathbf{5}$ was administered intraperitoneally in $20 \mu \mathrm{L}$ of DMSO at a concentration of $3 \mathrm{mg} / \mathrm{kg}$, while the control group received $20 \mu \mathrm{L}$ of DMSO only. For the oral administration study, chalcone 5 was administered orally in $100 \mu \mathrm{L}$ of corn oil at a concentration of $3 \mathrm{mg} / \mathrm{kg}$, while the control group received $100 \mu \mathrm{L}$ of corn oil only. The intraperitoneal group was administered twice a week, and the tumor size and body weight were measured at the same time. The oral group was administered three times a week, and the tumor size and body weight were measured simultaneously using a vernier caliper and a scale, respectively. Tumor size was calculated using the following formula (length $\times$ width $\times$ width $\times 0.5$ ). This animal protocol was approved by the Institutional Animal Care and Use Committee of the Graduate School of Medical Science, Kanazawa University, Kanazawa, Japan.

\subsection{Flow Cytometric Analysis}

MDA-MB-231 or KB-VIN $\left(7 \times 10^{4}\right.$ cells/well $)$ cells were seeded in a 12-well plate $24 \mathrm{~h}$ prior to treatment with compounds for $24 \mathrm{~h}$. Compounds were used against MDA-MB-231 or KB-VIN at a concentration threefold of their $\mathrm{IC}_{50}$ value. Harvested and $70 \% \mathrm{EtOH}$-fixed cells were stained with propidium iodide (PI) containing RNase (BD Bioscience, San Jose, 
CA, USA) and subjected to flow cytometry (BD LSRFortessa, BD Biosciences, San Jose, CA, USA). CA-4 at $200 \mathrm{nM}$ was used as a control tubulin polymerization inhibitor arresting cells at $\mathrm{G} 2 / \mathrm{M}$.

\subsection{Immunostaining}

MDA-MB-231 cells $\left(2.4 \times 10^{4}\right.$ cells /well) were grown on an 8-well chamber slide (LabTech, Waltham, USA) for $24 \mathrm{~h}$ prior to treatment with reagents. Cells were treated for $24 \mathrm{~h}$ with compound 5 or DMSO as a control for $24 \mathrm{~h}$. Cells were fixed in $4 \%$ paraformaldehyde in PBS and permeabilized with $0.5 \%$ Triton X-100 in PBS. Fixed cells were labeled with mouse monoclonal antibody to $\alpha$-tubulin (B5-1-2, Sigma, St. Louis, MO, USA) followed by FITC-conjugated antibody to mouse IgG (Sigma) [31]. Nuclei were labeled with DAPI (Sigma). Fluorescence labeled cells were observed using confocal microscope (LSM700, Zeiss, White Plains, NY, USA) controlled by ZEN (black edition) software (Zeiss). Confocal images were stacked and merged using ZEN (black edition) software. Final images were prepared using Adobe Photoshop.

\subsection{Affinity Purification of Binding Proteins}

Compound 9 was immobilized with Azide magnetic beads (TAS8848N1160, Tamagawa Seiki Co., Ltd. Iida, Japan) at a concentration of $125 \mu \mathrm{M}$ according to the manufacturer's method. PC-3 cell lysates in soluble buffer [10 mM HEPES, $150 \mathrm{mM} \mathrm{Na}_{2} \mathrm{SO}_{4}, 1 \mathrm{mM}$ EDTA, 2\% CHAPS, protease inhibitor (cOmplete Mini, Roche, Basel, Switzerland)] were incubated with or without compound $5(5 \mathrm{mM})$ at $37^{\circ} \mathrm{C}$ for $1 \mathrm{~h}$. The lysates $(30 \mu \mathrm{L})$ were incubated with the compound 9-immobilized beads $(10 \mu \mathrm{L})$ at $37^{\circ} \mathrm{C}$ for $1 \mathrm{~h}$. The beads were washed five times with soluble buffer $\left(200 \mu \mathrm{L}\right.$ each) and boiled at $95^{\circ} \mathrm{C}$ for $5 \mathrm{~min}$ with SDS-PAGE sample buffer $(10 \mu \mathrm{L})$. After the beads were removed using a magnetic stand, samples were analyzed by SDS-PAGE. The resultant gel was stained with CBB and the stained bands were cut out. The small portions of gel were treated with usual methods including reductive alkylation and in-gel digestion, and the resultant samples were analyzed with LC-MSMS (Orbitrap QE plus, Thermo Fisher, Waltham, MA, USA). The obtained peptide sequences were identified using Proteome Dicoverer software (Thermo Fisher, Waltham, MA, USA).

\section{Conclusions}

We developed seven $\alpha$-trifluoromethyl chalcones and evaluated them for antiproliferative activity against androgen-independent prostate cancer cell lines. Many of them showed potent activity with submicromolar $\mathrm{IC}_{50}$ values. The most effective chalcone 5 also displayed significant antiproliferative activity against taxane-resistant cell lines and antitumor activity in vivo with only $3 \mathrm{mg} / \mathrm{kg}$ administration in a mouse xenograft model. To investigate the intracellular target molecules, we prepared the chemical probe 9 and confirmed that its mode of action was the same as that of chalcone 5 by using flow cytometry. Affinity purification of binding proteins from PC-3 cell lysates using compound 9-immobilized beads revealed several candidates as the ligands for chalcone 5 . Some of them are known to stimulate cancer related cell growth.

Supplementary Materials: The following are available online. Figures S1-S40: 1H NMR, 13C NMR, FTIR, and UV-VIS spectra of compounds 2-11, Table S1: Detailed information of detected binding proteins.

Author Contributions: Y.S., A.M. and K.N.-G. designed this study; Y.S. and K.N.-G. designed and performed chemical experiments; A.M., K.I., R.N. and M.G. designed and performed biological experiments; Y.S., A.M., K.I., R.N., M.G. and K.N.-G. evaluated all results and wrote manuscript. All authors have given approval to the final version of the manuscript.

Funding: This research was funded by JSPS KAKENHI, grant number 25293024 awarded to K.N.-G. and $17 \mathrm{H} 04325$ awarded to A.M. This work was also supported in part by IBM junior faculty grant awarded to M.G. 
Institutional Review Board Statement: The study was conducted according to the guidelines of the Declaration of Helsinki, and approved by the Institutional Review Board of Kanazawa University.

Informed Consent Statement: Not applicable.

Data Availability Statement: The data presented in this study are available on request from the corresponding authors.

Acknowledgments: We appreciate critical comments, suggestions, and editing on the manuscript by Susan L. Morris-Natschke (UNC-CH). We thank the Microscope Service Laboratory (UNC-CH) for their expertise in confocal microscope. We also thank the Institute for Gene Research (KU) for their expertise in identification of the binding proteins.

Conflicts of Interest: The authors declare no competing financial interest.

Sample Availability: Samples of the compounds 1-9 are available from the authors.

\section{References}

1. Saito, Y.; Taniguchi, Y.; Hirazawa, S.; Miura, Y.; Tsurimoto, H.; Nakayoshi, T.; Oda, A.; Hamel, E.; Yamashita, K.; Goto, M.; et al. Effects of substituent pattern on the intracellular target of antiproliferative benzo[b]thiophenyl chromone derivatives. Eur. J. Med. Chem. 2021, under review.

2. Nakagawa-Goto, K.; Bastow, K.F.; Chen, T.H.; Morris-Natschke, S.L.; Lee, K.H. Antitumor agents 260. New desmosdumotin B analogues with improved in vitro anticancer activity. J. Med. Chem. 2008, 51, 3297-3303. [CrossRef]

3. Gillis, E.P.; Eastman, K.J.; Hill, M.D.; Donnelly, D.J.; Meanwell, N.A. Applications of fluorine in medicinal chemistry. J. Med. Chem. 2015, 58, 8315-8359. [CrossRef]

4. Saito, Y.; Mizokami, A.; Maeda, S.; Takahashi, K.; Izumi, K.; Goto, M.; Nakagawa-Goto, K. Bicyclic chalcones as mitotic inhibitors for overcoming androgen receptor-independent and multidrug-resistant prostate cancer. ACS Omega 2021, 6, $4842-4849$. [CrossRef] [PubMed]

5. Saito, Y.; Mizokami, A.; Tsurimoto, H.; Izumi, K.; Goto, M.; Nakagawa-Goto, K. 5'-Chloro-2,2'-dihydroxychalcone and related flavanoids as treatments for prostate cancer. Eur. J. Med. Chem. 2018, 157, 1143-1152. [CrossRef] [PubMed]

6. Al-Rifai, N.; Rücker, H.; Amslinger, S. Opening or closing the lock? When reactivity is the key to biological activity. Chem. Eur. J. 2013, 19, 15384-15395. [CrossRef] [PubMed]

7. Meanwell, N.A. Synopsis of some recent tactical application of bioisosteres in drug design. J. Med. Chem. 2011, 54, 2529-2591. [CrossRef] [PubMed]

8. Feldman, B.J.; Feldman, D. The development of androgen-independent prostate cancer. Nat. Rev. Cancer 2001, 1, 34-45. [CrossRef] [PubMed]

9. Yan, J.; Chen, J.; Zhang, S.; Hu, J.; Huang, L.; Li, X. Synthesis, evaluation, and mechanism study of novel indole-chalcone derivatives exerting effective antitumor activity through microtubule destabilization in vitro and in vivo. J. Med. Chem. 2016, 59, 5264-5283. [CrossRef] [PubMed]

10. Bueno, O.; Tobajas, G.; Quesada, E.; Estévez-Gallego, J.; Noppen, S.; Camarasa, M.-J.; Díaz, J.-F.; Liekens, S.; Priego, E.-M.; PérezPérez, M.-J. Conformational mimetics of the a-methyl chalcone TUB091 binding tubulin: Design, synthesis and antiproliferative activity. Eur. J. Med. Chem. 2018, 148, 337-348. [CrossRef]

11. Canela, M.-D.; Noppen, S.; Bueno, O.; Prota, A.E.; Bargsten, K.; Sáez-Calvo, G.; Jimeno, M.-L.; Benkheil, M.; Ribatti, D.; Velázquez, S.; et al. Antivascular and antitumor properties of the tubulin-binding chalcone TUB091. Oncotarget 2017, 8, 14325-14342. [CrossRef]

12. Bizet, V.; Pannecoucke, X.; Renaud, J.-L.; Cahard, D. Synthesis of $\beta-\mathrm{CF}_{3}$ ketones from trifluoromethylated allylic alcohols by rutheniumcatalyzed isomerization. J. Fluor. Chem. 2013, 152, 56-61. [CrossRef]

13. Sinistierra, J.V.; Garcia-Raso, A.; Cabello, J.A.; Marinas, J.M. An improved procedure for the Claisen-Schmidt reaction. Synthesis 1984, 6, 502-504. [CrossRef]

14. Akiyama, S.; Nakatsuji, S.; Nakashima, K.; Yamasaki, S. Diphenylmethane and triphenylmethane dye ethynovinylogues with absorption bands in the near-infrared. Dyes Pigm. 1988, 9, 459-466. [CrossRef]

15. Hino, K.; Nagai, Y.; Uno, H.; Masuda, Y.; Oka, M.; Karasawa, T. A novel class of potential central nervous system agents. 3-Phenyl-2-(1-piperazinyl)-5H-1-benzazepines. J. Med. Chem. 1988, 31, 107-117. [CrossRef]

16. Chen, X.-L.; Zhang, J.-M.; Shang, W.-L.; Lu, B.-Q.; Jin, J.-A. Microwave promoted one-pot preparation of fluorinated propargylamines and their chemical transformation. J. Fluor. Chem. 2012, 133, 139-145. [CrossRef]

17. Eisenberger, P.; Gischig, S.; Togni, A. Novel 10-I-3 hypervalent iodine-based compounds for electrophilic trifluoromethylation. Chem. Eur. J. 2006, 12, 2579-2586. [CrossRef]

18. Fang, Z.; Ning, Y.; Mi, P.; Liao, P.; Bi, X. Catalytic C-H $\alpha$-trifluoromethylation of $\alpha, \beta$-unsaturated carbonyl compounds. Org. Lett. 2014, 16, 1522-1525. [CrossRef] 
19. Nakagawa-Goto, K.; Wu, P.C.; Lai, C.Y.; Hamel, E.; Zhu, H.; Zhang, L.; Kozaka, T.; Ohkoshi, E.; Goto, M.; Bastow, K.F.; et al. Antitumor agents. 284. New desmosdumotin B analogues with bicyclic B-ring as cytotoxic and antitubulin agents. J. Med. Chem. 2011, 54, 1244-1255. [CrossRef]

20. Nakagawa-Goto, K.; Taniguchi, Y.; Watanabe, Y.; Oda, A.; Ohkoshi, E.; Hamel, E.; Lee, K.H.; Goto, M. Triethylated chromones with substituted naphthalenes as novel tubulin inhibitors. Bioorg. Med. Chem. 2016, 24, 6048-6057. [CrossRef]

21. Machioka, K.; Izumi, K.; Kadono, Y.; Iwamoto, H.; Naito, R.; Makino, T.; Kadomoto, S.; Natsugdorj, A.; Keller, E.T.; Zhang, J.; et al. Establishment and characterization of two cabazitaxel-resistant prostate cancer cell lines. Oncotarget 2018, 9, 16185-16195. [CrossRef] [PubMed]

22. Simons, L.J.; Caprathe, B.W.; Callahan, M.; Graham, J.M.; Kimura, T.; Lai, Y.; LeVine, H., III; Lipinski, W.; Sakkab, A.T.; Tasaki, Y.; et al. The synthesis and structure-activity relationship of substituted $N$-phenyl anthranilic acid analogs as amyloid aggregation inhibitors. Bioorg. Med. Chem. Lett. 2009, 19, 654-657. [CrossRef] [PubMed]

23. Ducki, S. Antimitotic chalcones and related compounds as inhibitors of tubulin assembly. Anticancer Agents Med. Chem. 2009, 9 , 336-347. [CrossRef] [PubMed]

24. Zhuang, C.; Zhang, W.; Sheng, C.; Zhang, W.; Xing, C.; Miao, Z. Chalcone: A privileged structure in medicinal chemistry. Chem. Rev. 2017, 117, 7762-7810. [CrossRef]

25. Naito, R.; Kano, H.; Shimada, T.; Makino, T.; Kadomoto, S.; Iwamoto, H.; Yaegashi, H.; Izumi, K.; Kadono, Y.; Nakata, H.; et al. A new flavonoid derivative exerts anti-tumor effects against androgen-sensitive to cabazitaxel-resistant prostate cancer cells. Prostate 2021, 81, 295-306. [CrossRef]

26. Wu, J.; Liu, T.; Rios, Z.; Mei, Q.; Lin, X.; Cao, S. Heat shock proteins and cancer. Trends. Pharmacol. Sci. 2017, 38, 226-256. [CrossRef]

27. Chistofk, H.R.; Vander Heiden, M.G.; Harris, M.H.; Ramanathan, A.; Gerszten, R.E.; Wei, R.; Fleming, M.D.; Schreiber, S.L.; Cantley, L.C. The M2 splice isoform of pyruvate kinase is important for cancer metabolism and tumour growth. Nature 2008, 452, 230-233. [CrossRef]

28. Capello, M.; Ferri-Borgogno, S.; Cappello, P.; Novelli, F. $\alpha$-Enolase: A promising therapeutic and diagnostic tumor target. FEBS J. 2011, 278, 1064-1074. [CrossRef]

29. Tsai, P.; Lin, C.-H.; Hsieh, C.-H.; Papakyrikos, A.M.; Kim, M.J.; Napolioni, V.; Schoor, C.; Couthouis, J.; Wu, R.-M.; Wszolek, Z.K.; et al. PINK1 phosphorylates MIC60/Mitofilin to control structural plasticity of mitochondrial crista junctions. Mol. Cell 2018, 69, 744-756. [CrossRef]

30. Stevenson, B.W.; Gorman, M.A.; Koach, J.; Cheung, B.B.; Marshall, G.M.; Parker, M.W.; Holien, J.K. A structural view of PA2G4 isoforms with opposing functions in cancer. J. Biol. Chem. 2020, 295, 16100-16112. [CrossRef]

31. Nakagawa-Goto, K.; Oda, A.; Hamel, E.; Ohkoshi, E.; Lee, K.-H.; Goto, M. Development of a novel class of tubulin inhibitor from desmosdumotin B with a hydroxylated bicyclic B-ring. J. Med. Chem. 2015, 58, 2378-2389. [CrossRef] 